\title{
Hastanede Yatan ve Geçici Üriner Kateterizasyon Uygulanan Hastalarda Kateterde Bakteriyel ve Fungal Kolonizasyonun Araştırılması
}

\author{
Evaluating the Fungal and Bacterial Colonization on Hospitalized Patients with Transient Urinary Catheterization
}

'İzmir Kâtip Çelebi Üniversitesi

Tip Fakültesi Enfeksiyon Hastalıkları ve Klinik Mikrobiyoloji Anabilim Dalı, İzmir, Türkiye

${ }^{2}$ Eskişsehir Osmangazi Üniversitesi Tip Fakültesi Enfeksiyon Hastalıkları ve Klinik Mikrobiyoloji Anabilim Dalı, Eskișehir, Türkiye

Correspondence:

Salih Atakan NEMLİ

İzmir Kâtip Çelebi Üniversitesi Tip Fakültesi Enfeksiyon Hastalıkları ve Klinik Mikrobiyoloji Anabilim Dalı, İzmir, Türkiye

e-mail: atanemli@yahoo.com

${ }^{1}$ Salih Atakan Nemli, ${ }^{2}$ Elif Doyuk Kartal (11)

Özet

Çalışmamızda geçici üriner kateterizasyon uygulanan hastalarda kateter içi ve eş zamanlı idrar örneği alınarak kateter lümeninde ve idrarda mikroorganizma kolonizasyonunun araștırılması ve olası risk faktörlerinin değerlendirilmesi amaçlandı. Eskișehir Osmangazi Üniversitesi Tip Fakültesi Eğitim, Araştırma ve Uygulama Hastanesi Genel Cerrahi, Üroloji, Ortopedi ve Travmatoloji, Kadın Hastalıkları ve Doğum kliniklerinde 3 aylık çalışma periyodu boyunca geçici üriner kateterizasyon uygulanan hastalarda kateter içi ve eş zamanlı idrar örneği alınarak kateter lümeninde ve idrarda üreyen mikroorganizmalar ve risk faktörleri değerlendirmeye alındı. Yatış esnasında üriner sistem enfeksiyonu (ÜSE) klinik ve bulguları olan hastalar çalışma kapsamı dışında bırakıld. Hastaların demografik bilgileri kaydedildi. Kateter lümeni veya idrar kültürlerinde üreyen mikroorganizmalar mini API cihazı yardımıyla tanımlandı. Veriler SPSS 15.0 istatistik programı ile değerlendirildi, $\mathrm{p}<0.05$ değerleri anlamlı olarak kabul edildi. Geçici üriner kateterizasyon uygulanan 129 hasta çalışmaya alındı. Çalışma grubunu oluşturan hastaların 56’sında (\%43.4) idrar ve/veya kateterinde mikroorganizma üremiş olup, 73’ünde (\%56.6) herhangi bir üreme saptanmadı. Yapılan bivaryet analizlerde kadın cinsiyet, kateterizasyon süresinin uzaması, acil-elektif kateterizasyon uygulanması, üriner kateterizasyonu uygulayan kişi, yakın dönemde üriner girişim öyküsü, diyabet öyküsü gibi bağımsız değişkenlerle idrar ve/veya kateter lümeninden mikroorganizma izolasyonu arasında anlamlı ilişki saptandı (her biri için $\mathrm{p}<0.05$ ). Olușturulan lojistik model sonuçlarına göre de kadın olmak $(\mathrm{OR}=2.730)$ ve kateterizasyon süresinin $>7$ gün olması $(\mathrm{OR}=3.232)$ geçici üriner kateterizasyon uygulanan hastalarda kateter içi ve idrarda mikroorganizmaların kolonizasyonu açısından önemli risk faktörleri olarak saptandı (her biri için $\mathrm{p}<0.05$ ). Kateter lümeni içinde mikroorganizmaların kolonizasyonu ile nozokomiyal üriner sistem enfeksiyonları (NÜSE) arasındaki iliski henüz tam olarak aydınlatılamamış olmakla beraber bakteriüri gelişimine öncülük edebilir. Risk faktörlerinin tanımlanması, kolonizasyonun ve diğer komplikasyonların önlenmesinde faydalı olabilir. Kateter ilişkili üriner sistem enfeksiyonu (KIÜSE) tanısı alan ve uygun antimikrobiyal tedaviye rağmen yeterli klinik yanıt alınamayan hastalarda üriner kateter içinde biyofilm gelișmiş olabileceği de göz önüne alınarak üriner kateterizasyonun sonlandırılması veya üriner kateterin değişimi tartışılması gereken konulardır.

Anahtar Kelimeler: Üriner kateterizasyon; bakteriüri; fungüri; kolonizasyon

\section{Abstract}

In this cross-sectional study, it's aimed to evaluate fungal and bacterial colonization and related risk factors in patients with transient urinary catheterization. Microorganisms yielded in the catheter lumen and urine those sampled from intra-catheter and simultaneous urine samples and related risk factors were evaluated. Study was conducted in General Surgery, Urology, Orthopedics and Traumatology, Gynecology and Obstetrics wards of Eskişehir Osmangazi University Faculty of Medicine Training, Research and Practice Hospital, in patients who underwent temporary urinary catheterization during the 3-month study period. Patients with clinical signs and symptoms of urinary tract infection during hospitalization were excluded from the study. Demographic data of the patients were recorded. The microorganisms were identified with mini API device. The data were evaluated by SPSS 15.0 statistical program, $\mathrm{p}<0.05$ values were considered significant. One hundred and twenty-nine patients underwent transient urinary catheterization were enrolled in this study. Urine culture and/or intraluminary swab cultures were positive in 56 (\% 43.4$)$ patients whom enrolled the study. Seventy three $(56.6 \%)$ of patients were culture negative. Bivariate analysis showed statistically significant relation between female gender, prolonged duration of catheterization, urgent-elective catheterization, person performing catheterization, previously urinary procedures, and presence of diabetes and microorganism isolation in urine and/or intraluminary swab cultures $(\mathrm{p}<0.05)$. Therefore in logistic regression model, female gender $(\mathrm{OR}=2.730)$ and duration of catheterization longer than 7 days $(\mathrm{OR}=3.232)$ were found as important risk factors for microorganism isolation in urine and/or intraluminary swab cultures $(p<0.05)$. Though the relation between intraluminary microorganism colonization and NUTIs is not clearly established, it may lead bacteriuria. Identifying risk factors can be useful in preventing colonization and other complications. In patients with catheter associated urinary tract infection and not responding adequate antimicrobial therapy, it may be considered to discontinue urinary catheterization or change urinary catheter.

Keywords: Urinary catheterization, funguri, funguria, colonization

Received 01.02.2021 Accepted 27.04.2021 Online published 28.04.2021 


\section{Giriş}

Üriner kateterizasyon, NÜSE gelişiminde önemli bir rol oynar. NÜSE'nin yaklaşık \%80'inin üriner kateterizasyon ile ilişkili olduğu gösterilmiştir(1). Üriner kateterde mikrobiyal kolonizasyon genellikle biyofilm oluşumuyla sonuçlanmaktadır. Biyofilm oluşturan mikroorganizmalar siklıkla antimikrobiyal tedaviye yüksek düzeyde dirençlidirler. Biyofilm içindeki bakteriler oluşturdukları mikro çevre içinde fonksiyonel bir birliktelik oluştururlar. Çeşitli enzimler ve mikroorganizmaların metabolitleri bu mikro çevre içinde yer alır. Bu birliktelikle diğer mikroorganizmaların eliminasyonu, antibiyotiklere karșı direnç ve bakteriyel çoğalmanın potansiyelize edilmesi sonucu ortaya çıkar. Ayrıca biyofilm sayesinde mekanik bir bariyer oluşarak, içeride bulunan bakterilerin doğal savunma sistemleri ve antibiyotiklerin etkisinden korunmas1 sağlanmış olur. $\mathrm{Bu}$ nedenle de gelişen enfeksiyonların eradikasyonu sorun teşkil etmektedir(1,2). Kateter lümeninden asendan olarak ilerleyen biyofilm de Kİ̈SE oluşumu için majör risk faktörü olarak değerlendirilmektedir. Kapalı drenaj sisteminin geliştirilmesiyle bu yolla gelişen enfeksiyonların sıklığı azaltılmıştır(3). Kİ̈SSE patogenezinde biyofilm oluşturan mikroorganizmaların önemi anlaşıldıktan sonra bunu önlemeye yönelik çeşitli stratejiler geliştirilmeye çalışılmıştır. Örneğin antibiyotikle kaplanmış üriner kateterlerin kısa süreli kateterizasyonda KIÜSE gelişimini geciktirdiğini veya engellediğini gösteren umut verici çalıșmalar yayınlanmıștır (4). İdrarda anlamlı bakteriürinin gösterilmesi üriner sistem enfeksiyonu (ÜSE) tanısında önemlidir. KIÜSE patogenezi ve tedavisindeki potansiyel önemine rağmen, kateter içinde kolonize olan mikroorganizmaların önemi henüz tam olarak açıklığa kavuşmamıştır. Bu nedenle kateter içi kolonizasyona sebep olan faktörlerin, bakteriüri ve/veya fungüri ile olan ilişkisinin açıklığa kavuşturulması kateter ilişkili enfeksiyonların azaltılmasına yönelik stratejilerin geliştirilmesine yardımcı olacaktır.

Hastaneye yatan hastaların yaklaşık dörtte birine yatış süresi boyunca üriner kateterizasyon uygulanmaktadır. Özellikle yoğun bakım ünitelerinde yatan hastalarda bu oran \%100'e kadar ulaşmaktadır. Kateterizasyon süresi hastanın yattığı kliniğe ve hasta popülasyonuna göre değişiklik göstermekte olup, genellikle gereksiz üriner kateterizasyon oranı yüksektir(5). Kateterizasyon süresi, kateter ilişkili mikrobüri için en önemli risk faktörüdür. Otuz güne kadar uygulanan kateterizasyon kısa süreli kateterizasyon olarak tanımlanırken, otuz günü aşan kateterizasyon uygulamaları uzun süreli kateterizasyon olarak tanımlanmaktadır. Üriner kateter uygulanan hastalarda en yaygın görülen komplikasyonlar bakteriüri ve olguların birçoğunda ortaya çıkan üriner sistem enfeksiyonlarıdır. Kısa süreli kateterizasyona bağlı bakteriürilerin çoğu asemptomatiktir. Ateş veya diğer ÜSE semptomlar1 \%10-30'a yakın bir oranda görülür. Katetere bağlı bakteriürili hastaların $\% 5$ 'inden daha azında bakteremi gelişmektedir. Bununla birlikte kateterize hasta sayısının fazlalığı nedeniyle nozokomiyal bakteremilerin \%15 kadar1 KIÜSE'ye bağlidır. KİÜSE sonucunda ölüm görülebilmesine karşın, atfedilen mortalitenin oran1 kesin olarak bilinmemektedir. Katetere bağlı bakteriürili hastalarda yapılan otopsilerde akut piyelonefrit, üriner taşlar veya perinefritik apseler tespit edilmiştir. Kateterle ilişkili üriner sistem enfeksiyonları diğer nozokomiyal enfeksiyonların kaynağı da olabilir.

$\mathrm{Bu}$ çalışmada Eskişehir Osmangazi Üniversitesi Tıp Fakültesi Eğitim, Araştırma ve Uygulama Hastanesi Genel Cerrahi, Üroloji, Ortopedi ve Travmatoloji, Kadın Hastalıkları ve Doğum Servisi'nde izlenen ve geçici üriner kateterizasyon uygulanan hastalarda, üriner kateter iç yüzeyinde kolonize olan ve eş zamanlı idrar kültüründe üreyen bakteriyel, fungal mikroorganizmaların araştırılması ve kolonizasyon için risk faktörlerinin saptanması amaçland. 


\section{Gereç ve Yöntemler}

\section{a. Hasta Seçimi}

$\mathrm{Bu}$ kesitsel tip çalışmada Eskişehir Osmangazi Üniversitesi Tıp Fakültesi Eğitim, Araştırma ve Uygulama Hastanesi Genel Cerrahi, Üroloji, Ortopedi ve Travmatoloji, Kadın Hastalıkları ve Doğum kliniklerinde 01.08.2009-01.10.2009 tarihleri arasinda geçici üriner kateterizasyon uygulanan hastalarda kateter içi ve eş zamanlı idrar örneği alınarak kateter lümeninde ve idrarda mikroorganizma kolonizasyonunun araştırılması, olası risk faktörlerinin değerlendirilmesi amaçland. Geçici üriner kateterizasyon uygulanan 129 hasta çalışmaya alındı. Yatış esnasında üriner system enfeksiyonu klinik ve bulguları olan hastalar çalışma kapsamı dışında bırakıldı. Geçici üriner kateterizasyonun sonlandırılması planlanan hastalar yattığ klinikte ziyaret edildi, hastaların demografik bilgileri kaydedildi.

\section{b. Örneklerin toplanmast}

Üriner sonda çıkarılırken sondanın proksimali povidonlu iyot çözeltisi ve steril gazlı bez kullanılarak temizlendi. Steril enjektör yardımıyla idrar örneği alındı. İdrar örneği, piyürinin saptanması için Thoma lamında x40 büyütmede incelenip milimetreküpteki lökosit sayısı belirlendi. Sonda çıkarıldıktan sonra steril şartlarda bisturi yardımıyla proksimalde 5 cm'lik uç kesilerek steril idrar kültür kabına alındı. Steril pamuklu çubuk ile sonda parçasında intraluminal olarak mekanik temizlik yapılarak kateter içindeki mikroorganizmaların pamuklu çubuğa geçmesi sağlandi. Pamuklu çubuk steril bir tüp içindeki $5 \mathrm{ml}$ steril serum fizyolojik içine yerleştirildi. 60 saniye boyunca vortekslenerek süspansiyon hazırland.

\section{c. Mikrobiyolojik testler}

Elde edilen süspansiyon ve daha önce alınan idrar örneği 0.01 ml'lik steril ölçülü öze yardımıyla Kanlı Agar, Eosin Metilen Blue
(EMB) Agar ve Sabouraud Dekstroz Agar (SDA) besi yerlerine ekildi. 37 oC'de 24 saat etüvde inkübe edildi. 24 saat sonra üremeler değerlendirildi. Besi yerlerinde oluşan üremelerden alınan örnekler Gram boyama metodu ile boyanarak boyanma özelliklerine ve morfolojilerine göre sinıflandirıldı. Eğer birden fazla morfolojik özellik gösteren üreme olmuşsa tek koloni ekimleri yapılarak saf kültür elde edildi. Üreyen mikroorganizmalar mini API cihazı yardımıyla uygun kitler kullanılarak, üretici firmanın talimatlarına uygun olarak tanımland.

\section{d. İstatistiksel analiz}

Veriler bilgisayar ortamında SPSS 15.0 istatistik programına girilerek değerlendirildi. İstatistiksel analizlerden ki kare testi, student $\mathrm{t}$ testi, Pearson korelasyon testi kullanıldi. İki değişkenli analizlerde anlamlı bulunan bağımsız değişkenlerle Backward Wald Lojistik Regresyon modeli oluşturuldu. Hosmer Lemeshov uyum testi ile en uygun sonuçları veren adım 3'ün sonuçları sunulmuştur.

Çalışma, Eskişehir Osmangazi Üniversitesi Etik Kurulu'nun 30.06.2009 tarih ve 65 sayılı kararı ile onay alınarak gerçekleştirildi.

\section{Bulgular}

Çalışma 129 hastanın katılımıyla tamamlandı. Çalışma grubunu oluşturan 129 hastanın 80'i (\%62.0) erkek, 49 (\%38.0) kadındı. Hastaların yaş ortalaması $57.24 \pm 13.36$ yıl olup yaşları 15 ile 86 arasında değişmekteydi.

Hastaların serviste kaldıkları süre boyunca 56'sinın (\%43.4) idrar ve/veya üriner kateterinde mikroorganizma üremiş olup, 73 'ünde (\%56.6) hiçbir üreme olmamıştır.

İdrar ve kateter kültüründe üreyen mikroorganizmaların dağılımı Tablo 1'de sunulmuştur. Escherichia coli idrar ve kateter kültürlerinde en sık saptanan mikroorganizma olarak saptand1 (Tablo 2, Tablo 3). 
Tablo 1. İdrar ve kateter kültürlerinde üreyen mikroorganizmaların dağılımı.

\begin{tabular}{lccc}
\hline & Gram Pozitif Bakteri & Gram Negatif Bakteri & Maya \\
\hline İdrar kültürü & $13(\% 15.1)$ & $15(\% 17.4)$ & $\mathbf{4}(\% 4.6)$ \\
Kateter kültürü & $22(\% 25.6)$ & $27(\% 31.4)$ & $\mathbf{5 ( \% 5 . 9 )}$ \\
Toplam & $35(\% 40.7)$ & $42(\% 48.8)$ & $\mathbf{9 ( \% 1 0 . 5 )}$ \\
\hline
\end{tabular}

Tablo 2. İdrar örneklerinde bakteri ve mayaların dağılımı.

\begin{tabular}{|l|c|c|}
\hline \multicolumn{1}{|c}{ Mikroorganizma } & Üreme(n) & Oran(\%) \\
\hline Escherichia coli & 12 & 37.6 \\
\hline Enterococcus faecium & 5 & $\mathbf{1 5 . 7}$ \\
\hline Staphylococcus epidermidis & 3 & 9.3 \\
\hline Candida glabrata & 2 & 6.3 \\
\hline Candida albicans & 2 & 6.3 \\
\hline Staphylococcus hominis & 1 & 3.1 \\
\hline Staphylococcus warneri & 1 & 3.1 \\
\hline Staphylococcus haemolyticus & 1 & 3.1 \\
\hline Staphylococcus cohnii & 1 & 3.1 \\
\hline Pseudomonas aeruginosa & 1 & 3.1 \\
\hline Acinetobacter baumannii & 1 & 3.1 \\
\hline Proteus mirabilis & 1 & 3.1 \\
\hline Brevibacillus brevis & 1 & 3.1 \\
\hline Toplam & 32 & $\mathbf{1 0 0}$ \\
\hline
\end{tabular}

Tablo 3. Kateter kültüründe üreyen mikroorganizmalar.

\begin{tabular}{|lll}
\hline Mikroorganizma & Üreme (n) & Oran(\%) \\
\hline Escherichia coli & 13 & $\mathbf{2 4 . 0}$ \\
\hline Pseudomonas aeruginosa & 6 & $\mathbf{1 1 . 0}$ \\
\hline Staphylococcus epidermidis & 5 & 9.2 \\
\hline Enterococcus faecium & 4 & 7.4 \\
\hline Enterococcus faecalis & 4 & 7.4 \\
\hline Acinetobacter baumannii & 3 & $\mathbf{5 . 5}$ \\
\hline Candida glabrata & 3 & $\mathbf{5 . 5}$ \\
\hline Staphylococcus aureus & 2 & 3.7 \\
\hline Staphylococcus haemolyticus & 2 & 3.7 \\
\hline Klebsiella pneumoniae & 2 & 3.7 \\
\hline Candida albicans & 2 & 3.7 \\
\hline Staphylococcus hominis & 1 & $\mathbf{1 . 9}$ \\
\hline Proteus stuarti & 1 & 1.9 \\
\hline
\end{tabular}




\begin{tabular}{lll}
\hline Micrococcus luteus & 1 & $\mathbf{1 . 9}$ \\
Corynobacterium striatum & 1 & 1.9 \\
Moraxellalacunata & 1 & 1.9 \\
Enterococcus hirae & 1 & 1.9 \\
Listeria monocytogenes & 1 & $\mathbf{1 . 9}$ \\
Aeromonas salmonicida & 1 & $\mathbf{1 . 9}$ \\
\hline Toplam & $\mathbf{5 4}$ & $\mathbf{1 0 0 . 0}$ \\
\hline
\end{tabular}

Hastaların 66's1 (\%51.2) Genel Cerrahi, 41'i (\%31.8) Üroloji, 14'ü $\quad(\% 10.9)$ Beyin Cerrahisi, 4'ü (\%3.1) Ortopedi, 4'ü (\%3.1) Kadın Hastalıkları ve Doğum Servisi'nde izlenmekteydi. Yapılan ki-kare testinde hastaların izlendiği servislere göre idrar ve/veya kateter lümeni içinden alınan kültürlerde üreme arasında istatistiksel olarak anlamlı bir fark saptanmad $(\mathrm{p}=0.695)$.

Hastaların 49'u (\%38.0) kadın, 80'i (\%62.0) erkekti. Kadın hastaların 29'unda (\%59.2), erkek hastaların 27'sinde (\%33.8) idrar ve/veya kateter lümeni içinden alınan kültürlerde üreme saptand1. Yapılan ki-kare testiyle çalıșmaya alınan kadın hasta grubunda idrar ve/veya kateter lümeni içinden alınan kültürlerde üreme saptanmasının erkek hasta grubuna göre istatistiksel olarak anlaml şekilde yüksek olduğu saptanmıştır $(\mathrm{p}=0.005)$. İdrar ve/veya kateter lümeni içinden alınan örneklerdeki üremelerin hastaların cinsiyetlerine göre dağılımı Tablo 4'de sunulmuştur.

Tablo 4.İdrar ve/veya kateter lümeni içinden alınan örneklerdeki üremelerin hastaların cinsiyetlerine göre dağıllımı.

\begin{tabular}{|c|c|c|c|}
\hline & $\begin{array}{l}\text { Üreme olmayan } \\
\text { hastalar n }(\%)\end{array}$ & $\begin{array}{c}\text { Üreme olan } \\
\text { hastalar n (\%) }\end{array}$ & Toplam \\
\hline Kadın & $20(40.8)$ & $29(59.2)$ & $49(100.0)$ \\
\hline Erkek & $53(66.3)$ & $27(33.8)$ & $80(100.0)$ \\
\hline Toplam & $73(56.7)$ & $56(43.3)$ & $129(100.0)$ \\
\hline${ }^{*} p<0.05$ & & & \\
\hline
\end{tabular}

Çalışmaya alınan hastalarda üriner kateterizasyon süresi 1-17 gün arasında değişmekte olup, ortalama $4.84 \pm 3.43$ gündü. Hastaların 107'sinde (\%82.9) kateterizasyon 0-7 gün sürerken, 22'sinde (\%17.1) 7-17 gün arasında sürmüştür. Kateterizasyonun 0-7 gün sürdüğ̈ hastaların 40'1nda (\%37.4), 7-17 gün süren hastaların 16'sında (\%72.7) idrar ve/veya kateter lümeni içinden alınan örneklerde üreme saptand1. Yapılan ki-kare testiyle üriner kateterizasyonun 7-17 gün arasında sürdüğü hasta grubunda idrar ve/veya kateter lümeni içinden alınan örneklerde üreme saptanmasının üriner kateterizasyonun 0-7 gün sürdüğü hasta grubuna göre istatistiksel olarak anlaml şekilde yüksek olduğu saptanmıştır $(p=0.002)$. İdrar ve/veya kateter lümeni içinden alınan örneklerdeki üremelerin hastaların kateterizasyon süresine göre dağglımı Tablo 5'de sunulmuştur. 
Tablo 5 . İdrar ve/veya kateter lümeni içinden alınan kültürlerde üremelerle hastaların kateterizasyon süresine göre dağılımı.

\begin{tabular}{|c|c|c|c|}
\hline $\begin{array}{l}\text { Kateterizasyon } \\
\text { Süresi }\end{array}$ & $\begin{array}{l}\text { Üreme olmayan } \\
\text { hastalar n (\%) }\end{array}$ & $\begin{array}{c}\text { Üreme olan } \\
\text { hastalar n (\%) }\end{array}$ & Toplam \\
\hline 0-7 gün & $67(62.6)$ & $40(37.4)$ & $107(100.0)$ \\
\hline 7-17 gün & $6(27.3)$ & $16(72.7)$ & $22(100.0)$ \\
\hline Toplam & $73(56.6)$ & $56(43.4)$ & $129(100.0)$ \\
\hline$*_{p} p=0.002$ & & & \\
\hline
\end{tabular}

Hastaların 31'ine (\%24.0) acil şartlarda üriner kateterizasyon uygulandığ elektif şartlarda üriner kateterizasyon uygulandığı saptanmıştır. Acil üriner kateterizasyon uygulanan hastaların 20'sinde (\%64.5), elektif üriner kateterizasyon uygulanan hastaların 36'sında (\%36.7) idrar ve/veya kateter lümeni içinden alınan örneklerde üreme saptand. Yapılan ki-kare testiyle acil üriner kateterizasyon uygulanan hasta grubunda idrar ve/veya kateter lümeni içinden alınan örneklerde üreme saptanmasinın elektif üriner kateterizasyon uygulanan hasta grubuna göre istatistiksel olarak anlamlı şekilde yüksek olduğu saptanmıştır $(\mathrm{p}=0.007)$.

Hastaların $\quad 56$ 'sinda $\quad(\% 43.4)$ üriner kateterizasyonun sonlandırılması sirasinda alınan idrar örneğinde piyüri saptandı. Üreme olmayan hastalarda idrarda ortalama beyaz küre sayıs1 3.8 \pm 9.52 , üreme olan hastalarda, $57.1 \pm 133.2$ olarak saptandi. Yapılan Pearson korelasyon testi ile idrarda ve/veya kateterde üreme olması ile idrardaki beyaz küre sayısı arasında istatistiksel olarak anlamlı zayif pozitif bir ilişki bulundu $(\mathrm{p}<0.05)$.

İdrar kateter çapı ile idrar ve/veya kateter lümeni içinden alınan kültürlerde üreme arasında istatistiksel olarak anlamlı bir ilişki saptanmamıştır $(\mathrm{p}=0.503)$.

Hastaların 47'sine (\%36.4) üriner kateterizasyonun hemşireler tarafindan, 82'sine (\%63.6) doktorlar tarafindan uygulandığı saptanmıştır. Üriner kateterizasyonun hemşireler tarafindan uygulandığ 1 hastaların 27'sinde (\%57.4), doktorlar tarafindan uygulandığı hastaların 29'unda (\%35.4) idrar ve/veya kateter lümeni içinden alınan kültürlerde üreme saptandı. Hemşireler tarafindan üriner kateterizasyon uygulanan hasta grubunda idrar ve/veya kateter lümeni içinden alınan kültürlerde üreme saptanmasının doktorlar tarafindan üriner kateterizasyon uygulanan hasta grubuna göre istatistiksel olarak anlaml şekilde yüksek olduğu saptanmıştır $(\mathrm{p}=0.015)$.

Hastaların 20'sinde (\%15.5) yakın dönemde üriner sisteme girişim öyküsü bulunmaktayken, 109'unda (\%84.5) böyle bir öykü saptanmadı. Üriner girişim öyküsü olan hastaların 13'ünde (\%65.0), üriner girişim öyküsü olmayan hastaların 43'ünde (\%39.4) idrar ve/veya kateter lümeni içinden alınan kültürlerde üreme saptandı. Üriner girişim öyküsü olan hasta grubunda idrar ve/veya kateter lümeni içinden alınan kültürlerde üreme saptanmasının üriner girişim öyküsü olmayan hasta grubuna göre istatistiksel olarak anlamlı şekilde yüksek olduğu saptanmıştır $(\mathrm{p}=0.034)$.

Hastaların 11'inde (\%8.5) diyabet öyküsü bulunmaktayken, 118'inde(\%91.5) böyle bir öykü saptanmadi. Diyabet öyküsü olan hastaların 8'inde (\%72.7), diyabet öyküsü olmayan hastaların 48'inde (\%40.7) idrar ve/veya kateter lümeni içinden alınan kültürlerde üreme saptandı. Yapılan ki-kare testiyle diyabet öyküsü olan hasta grubunda idrar ve/veya kateter lümeni içinden alınan kültürlerde üreme saptanmasının diyabet öyküsü olmayan hasta grubuna göre istatistiksel olarak anlamlı şekilde yüksek olduğu saptanmıştır $(\mathrm{p}=0.040)$. 
İdrar ve/veya kateter lümeni içinden alınan kültürlerde üremelerle hastalarda üriner obstrüksiyon öyküsüne, taş öyküsüne, üriner kateterizasyonun uygulandığ 1 zamana, üriner kateterizasyon sebebine, uygun endikasyonda üriner kateterizasyon uygulanmasina, üriner girişim öyküsüne, malignite öyküsüne, kronik renal yetmezlik öyküsüne, cerrahi operasyon uygulanmasına, cerrahi operasyon bölgesine, antibiyotik kullanımına göre dağılımlara bakılmış ve herhangi bir ilişki saptanamamıştır (her biri için $\mathrm{p}>0.05$ ).

Nötropeni, transplantasyon öyküsü, immunsupresyon, diyaliz öyküsü, üriner sistemde sık enfeksiyon öyküsü ve silikon sonda kullanımının idrar ve/veya üriner kateter kültüründe üreme varlığı üzerine istatistiksel olarak anlamlı bir etkisi olmadığ 1 saptanmıştır(her biri için $\mathrm{p}>0.05$ ).
İki değişkenli analizlerde anlamlı bulunan bağımsız değişkenlerle (cinsiyet, kateterizasyon süresi, acil-elektif kateterizasyon, üriner kateterizasyonu uygulayan kişi, yakın dönemde üriner girişim öyküsü, diyabet öyküsü) oluşturulan lojistik model sonuçları Tablo 6'da verilmiştir. Lojistik model sonuçlarına göre, kadın olmak $(\mathrm{OR}=2.730)$ ve kateter süresinin $>7$ gün olmas1 $(\mathrm{OR}=3.232)$ geçici üriner kateterizasyon uygulanan hastalarda idrar ve/veya üriner kateter kültüründe mikroorganizma üremesi için bağımsız risk faktörleriydi (her biri için $\mathrm{p}<0.05$ ). Üriner kateter kullanımında mikroorganizma üremesi ile anlamlı ilișkili bağımsız değişkenlerle oluşturulan lojistik model sonuçları Tablo 6'da sunulmuştur.

Tablo 6 . Üriner kateter kullanımında mikroorganizma üremesi ile anlamlı ilişkili bağımsız değişkenlerle oluşturulan lojistik model sonuçları.

\begin{tabular}{|c|c|c|c|c|c|c|c|}
\hline Adım 3 & B & $\begin{array}{c}\text { Standard } \\
\text { hata }\end{array}$ & Wald & $s d^{*}$ & $\mathbf{P}$ & $\mathbf{O R} * *$ & $\begin{array}{l}\text { \%95GA } * * * \\
\text { (enaz-ençok) }\end{array}$ \\
\hline \multicolumn{8}{|c|}{ Cinsiyet (referans=erkek) } \\
\hline Kadın & $\begin{array}{l}1.00 \\
4\end{array}$ & 0.393 & 6.524 & 1 & 0.011 & 2.730 & $1.263-5.899$ \\
\hline \multicolumn{8}{|c|}{ Kateter süresi (referans=0-7gün) } \\
\hline >7gün & $\begin{array}{l}1.17 \\
3\end{array}$ & 0.546 & 4.613 & 1 & 0.032 & 3.232 & $1.108-9.429$ \\
\hline Constant & $\begin{array}{l}0.99 \\
2\end{array}$ & 0.271 & 13.435 & 1 & 0.000 & 0.371 & \\
\hline
\end{tabular}

Hosmer and Lemeshow Test $X^{2}=0.199 ; p=0.978$

${ }^{*} d=$ Serbestlik derecesi, $* *$ OR= Odds Oranı, *** GA= GüvenAralı̆

\section{Tartışma ve Sonuç}

Kateter ilişkili üriner sistem enfeksiyonları farklı hasta gruplarında sıklıkla karşılaşılan ve önemli morbiditeye sebep olan enfeksiyonlardır(5). Nozokomiyal üriner sistem enfeksiyonları, hastane enfeksiyonlarının önemli bir kısmını olușturur ve siklıkla üriner sistem kateterizasyonu sonrası gelişir(6). Ülkemizden yapılan bir çalışmada nozokomiyal üriner sistem enfeksiyonlarının \%97.3'ünün üriner kateterizasyonla ilișkili olduğu bildirilmiştir(7). European Society of Clinical Microbiology and Infectious Diseases
(ESCMID) çalışma grubu bu oranı \%63 olarak bildirmiştir(8).

Üriner kateterler en eski ve en s1k kullanılan medikal araçlardan biridir(9). Üriner kateterler, spinal kord yaralanması olan hastalarda, bakım evleri, hastaneler gibi yerlerde sıklıkla kullanılmakta, ilişkili olarak gelişen enfeksiyonlar sağlı bakım giderlerinde de büyük maliyet artışlarına neden olmaktadır(5). Ayrıca üriner sistem enfeksiyonları, hasta konforunda bozulma, mobilitenin sinırlanması gibi olumsuz sonuçlara sebep olabilir(10). NÜSE ile üriner kateterizasyon arasındaki ilişki, çeşitli hasta gruplarında, çeşitli kliniklerde risk 
faktörlerinin belirlenmesi açısından geniş kapsamlı olarak araştırılmıştır. Birçok çalışmada üriner kateterizasyon süresinin uzaması, kadın cinsiyet, kateter bakımında yapılan hatalar, ileri yaş, sistemik antimikrobiyallerin kullanılmamas1, diyabet öyküsü gibi değişkenler KIÜSE gelişiminde risk faktörü olarak tanımlanmıştır( $5,11,12)$.

Çalışmamızda iki değişkenli analizlerde; kadın cinsiyet, üriner kateterizasyon süresinin $>7$ gün olması, acil şartlarda üriner kateterizasyon uygulanmas1, üriner kateterizasyon uygulayan kişi, yakın dönemde üriner girişim öyküsü, diyabet öyküsü gibi parametrelerle geçici üriner kateterizasyon uygulanan hastalarda idrar ve/veya kateter lümeni içinden alınan içinden alınan örneklerde üreme saptanması açısından anlamlı farklılık saptand. Ancak lojistik model sonuçlarına göre; bağımsız değişkenlerden sadece kadın olmak ve kateter süresinin $>7$ gün olması geçici üriner kateterizasyon uygulanan hastalarda idrar ve/veya üriner kateter kültüründe mikroorganizma üremesi için bağımsız risk faktörleri olarak saptandi.

Uygunsuz endikasyonda ve gerektiğinden uzun süreli üriner kateterizasyon uygulanmas1, hastane enfeksiyonları ve mortalitede artışlara sebep olmaktadır(13). Bu konuda yapılan çalışmalarda uygunsuz üriner kateterizasyon oranını Munasinghe ve ark. \%38 (14), Gokula ve ark. \%54 (15), Hazelett ve ark. \%45.8 (16) olarak saptamışlardır. Avrupa'da 25 ülkede 141 hastanede NÜSE'lerin araştırıldığı bir çalışmada, hastaların \%7.6'sında üriner kateterizasyonun uygun endikasyonda uygulanmadığ saptanmıştır(8). Bizim çalışmamızda hastaların 23'ünde (\%17.8) uygunsuz endikasyonda üriner kateterizasyon uygulaması saptanmıştır. Uygunsuz üriner kateterizasyon oranlarımı literatürdeki verilerden düşük olmakla birlikte, Avrupa ortalamasından yüksektir. $\mathrm{Bu}$ oranların düşürülmesi başta KIÜSE ve diğer komplikasyonların azaltılmasına katk1 sağlayacaktır.

Yapılan çalışmalar üriner kateterizasyon süresinin KIÜSE gelişiminde en önemli risk faktörü olduğunu göstermiştir. Tissot ve ark.
(17) ise kateterizasyon süresinin $>11$ gün olmasının bu riski 20 kat arttırdığını göstermişlerdir. Wald ve ark. (18) majör cerrahi operasyon yapılan 35904 hasta üzerinde yaptıkları çalışmada üriner kateterizasyon süresinin 2 günden uzun olduğu hasta grubunda Kï̈SE gelişimi riskinin diğer hastalara oranla anlamlı olarak yüksek olduğunu göstermişlerdir. Colau ve ark.(19) transüretral prostat rezeksiyonu uygulanan 101 hastada yaptıkları çalışmada, üriner kateterizasyon süresinin 3 günü geçmesini bakteriüri gelişimi açısından anlamlı risk faktörü olarak tanımlamışlardır. Apisarnthanarak ve ark.(10) 450 yataklı bir hastanede üriner kateterizasyon uygulanan hastaları değerlendirdikleri bir çalıșmada kateterizasyon süresinin uzadığ 1 hastalarda nozokomiyal üriner sistem enfeksiyonlarının daha sık geliştiğini belirlemişlerdir. $\mathrm{Bu}$ hastalarda hastanede yatış süresinin anlamlı oranda uzadığını göstermişlerdir. Bizim çalışmamızda da üriner kateterizasyon süresinin $>7$ gün olmasının $(\mathrm{p}=0.002)$ geçici üriner kateterizasyon uygulanan hastalarda idrar ve/veya üriner kateter lümeni içinden alınan kültürde mikroorganizmaların üreme riskini 3.2 kat arttırdığı saptanmıştır. Çalışmamızın sonuçları bu açıdan literatürle uyumludur. Üriner kateterizasyonun mümkün olan en kisa sürede sonlandırılmasıyla bakteriüri/fungüri ve ÜSE gelişme riski asgariye indirilebilir.

Pek çok çalışmada bakteriüri gelişimi ile cinsiyetin rolü değerlendirilmiş, erkeklerle karşılaştırıldığında kadınlarda KIÜSE'nin daha sık geliştiği gösterilmiştir. Tambyah ve ark.(11) 1497 kateterize hastada yaptıkları bir çalışmada KiÜSE gelişen hastaların \%66'sının kadın olduğunu bildirmiş̧ir. Leone ve ark. (20) altı yataklı bir yoğun bakımda yaptıkları çalışmada kadın cinsiyeti KIÜSE gelişimi için bağımsız bir risk faktörü olarak bulmuşlardır. Puri ve ark.(21), Laupland ve ark.(22), Johnson ve ark.(23) da çeşitli hasta grupları üzerinde yaptıkları çalışmalarda kadın cinsiyet ile KIÜSE gelişimi arasındaki ilişkiyi göstermişlerdir. Çalışmamızda geçici üriner kateterizasyon uygulanan kadın hastaların \%59.2'sinde idrar ve/veya kateter lümeni içinden alınan örneklerde üreme saptandı. Literatürle benzer şekilde kadın 
cinsiyetin geçici üriner kateterizasyon uygulanan hastalarda idrar ve/veya üriner kateterde mikroorganizmaların üreme riskini 2.7 kat arttırdığı saptanmıştır.

Araştırmamızda geçici üriner kateterizasyon uygulanan hastaların \%43.4'ünde idrar ve/veya kateter lümeni içinden alınan örneklerin kültürlerinde mikroorganizma varlığı saptanmıştır. Ayrıca, idrar ve/veya üriner kateter lümeni içinden alınan örneklerde üreme olması için, kadınlarda riskin erkeklere oranla 2.7 kat, üriner kateterizasyon süresinin $>7$ gün olanların, $<7$

\section{KAYNAKLAR}

1. Barford JM, Anson K, Hu Y et al. A model of catheter-associated urinary tract infection initiated by bacterial contamination of the catheter tip. BJU Int. 2008; 102: 67-74.

2. Matsukawa M, Kunishima $\mathrm{Y}$, Takahashi $\mathrm{S}$ et al. Bacterial colonization on intraluminal surface of urethral catheter. Urology. 2005;65: 440-4.

3. Warren JW. Nosocomial urinary tract infections. Mandell GL, Bennett JE, Dolin R (eds). Principles and practice of infectious diseases, 6th ed. Philadelphia: Elsevier Churchill Livingstone; 2005. pp. $3370-80$

4. Johnson JR, Kuskowski MA, Wilt TJ. Systematic review: antimicrobial urinary catheter $\mathrm{s}$ to prevent catheter-associated urinary tract infection in hospitalized patients. Ann Intern Med. 2006. 144:116-26.

5. Saint S, Chenoweth CE. Biyofilms and catheterassociated urinary tract infections. Infect Dis Clin North Am. 2003;17:411-32

6. Henderson HK, Fischman N. Preventionand Control of Hospital-Acquired Infections. Goldman L, Ausiello D (eds). Cecil Medicine, 23rd ed. Philadelphia: Saunders Elsevier; 2008. pp. 212432.

7. Esen S, Leblebicioglu H. Prevalence of nosocomial infections at intensive care units in Turkey: a multicentre 1-day point prevalence study. Scand J Infect Dis. 2004; 36:144-8.

8. Bouza E, San Juan R, Munoz P et al. European perspective on nosocomial urinary tract infections II. Report on incidence, clinical characteristics and outcome (ESGNI-004 study). European Study Group on Nosocomial Infection. Clin Microbiol Infect. 2001; 7:532-42.

9. Ferrieres L, Hancock V, KlemmP. Specific selection for virulent urinary tract infectious Escherichia coli strains during catheter-associated biyofilm formation. FEMS ImmunolMed Microbiol.2007;51:212-9.

10. Apisarnthanarak A, Rutjanawech S, Wichansawakun $\mathrm{S}$ et al. Initial inappropriate urinary catheters use in a tertiary-care center: gün olanlara göre 3.2 kat fazla olduğu saptand1. KIÜSE tanis1 alan ve uygun antimikrobiyal tedaviye rağmen yeterli klinik yanıt alınamayan hastalarda üriner kateter içinde biyofilm gelişmiş olabileceği de göz önüne alınarak üriner kateterizasyonun sonlandırılması veya üriner kateterin değişimi mutlaka değerlendirilmelidir.

\section{TEŞEKKÜR}

Bu çalışmanın yayın aşamasına getirilmesindeki katkılarından dolayı İzmir Katip Çelebi Tip Fakültesi Halk Sağllğ AD ögrretim üyesi sayın Prof. Dr. Mustafa TÖZÜN'e teșekkür ederiz. incidence, risk factors, and outcomes. Am J Infect Control.2007;35:594-9.

11. Tambyah PA, Maki DG. Catheter-associated urinary tract infection is rarely symptomatic: a prospective study of 1,497 catheterized patients. ArchIntern Med.2000;160:678-82.

12. Maki DG, TambyahPA. Engineering out the risk of infection with urinary catheters. Emerg InfectDis. 2001; 7:342-7.

13. Raffaele G, Bianco A, Aiello $M$ et al. Appropriateness of use of indwelling urinary tract catheters in hospitalized patients in Italy. Infect Control Hosp Epidemiol. 2008; 29:279-81.

14. Munasinghe RL, Yazdani $\mathrm{H}$, Siddique $\mathrm{M}$, et al. Appropriateness of use of indwelling urinary catheters in patients admitted to the medical service. Infect Control Hosp Epidemiol. 2001; 22:647-9.

15. Gokula RR, Hickner JA, Smith MA.Inappropriate use of urinary catheters in elderly patients at a midwestern community teaching hospital. $\mathrm{Am} \mathrm{J}$ Infect Control. 2004; 32:196-9.

16. Hazelett SE, Tsai M, Gareri $M$ et al. The association between indwelling urinary catheter use in the elderly and urinary tract infection in acute care. BMC Geriatr.2006;6:15.

17. Tissot $\mathrm{E}$, Limat $\mathrm{S}$, Cornette $\mathrm{C}$ et al. Risk factors for catheter-associated bacteriuria in a medical intensive care unit. Eur J Clin Microbiol Infect Dis.2001; 20:260-2.

18. Wald HL, Ma A, Bratzler DW et al. Indwelling urinary catheter use in the postoperative period: analysis of the national surgical infection prevention project data. ArchSurg. 2008;143:5517.

19. Colau A, Lucet JC, Rufat P et al. Incidence and risk factors of bacteriuria after transurethral resection of the prostate. EurUrol. 2001; 39:272-6.

20. Leone M, Albanese J, Garnier F et al. Risk factors of nosocomial catheter-associated urinary tract infection in a polyvalent intensive care unit. Intensive Care Med.2003;29:1077-80. 
21. Puri J, Mishra B, Mal A, et al. Catheter associated urinary tract infections in neurology and neuro surgical units. $J$ Infect. 2002;44:171-5.

22. Laupland KB, Zygun DA, Davies HD et al. Incidence and risk factors for acquiring nosocomial urinary tract infection in the critically ill. J CritCare. 2002;17:50-7.

23. Johnson EN, Marconi VC, MurrayCK.Hospitalacquired device-associated infections at a deployed military hospital in Iraq. $J$ Trauma.2009;66:157-63. 